\title{
GERARDO REICHEL-DOLMATOFF
}

\author{
$1912-1994$
}

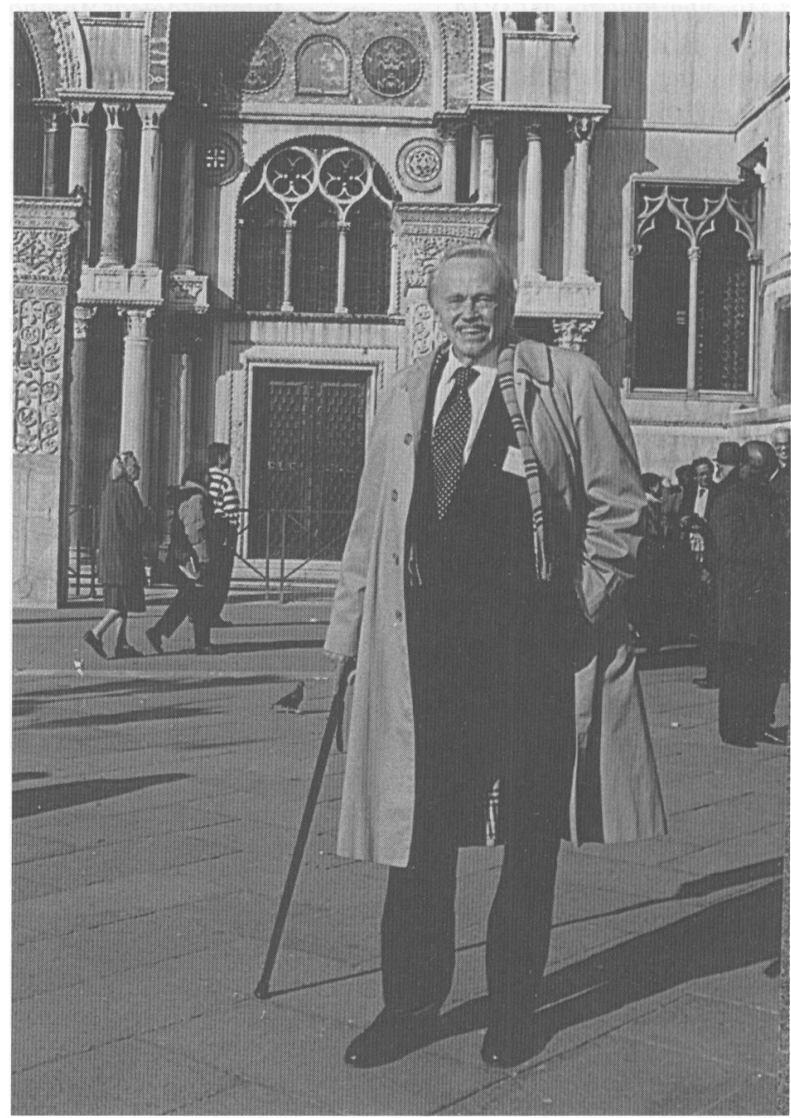

$\mathrm{O}$ n May 16, 1994, the academic community lost one of its greatest researchers. The father of Colombian anthropological archaeology died in Bogotá. More than 50 years of continuous research by Gerardo Reichel-Dolmatoff and his wife, Alicia, have built a solid foundation for anthropological academia in Colombia. To Reichel-Dolmatoff no division existed between anthropological and archaeological research. He always thought of research holistically, following the model of knowledge that developed through work with the native inhabitants of Colombia. More than once he expressed the view that if humanity wanted to survive and stop its destruction of nature, we had to start learning the lessons of the past and incorporating them into our understanding, and that some of the models developed by indigenous societies may be worth emulating. His vast knowledge of several fields from botany to linguistics, and his impressive command of Spanish, English, German, and French, and an understanding of several indigenous 'languages made him a real encyclopedist.

American Antiquity, 61(1), 1996, pp. 52-56.

Copyright $(\mathcal{O}$ by the Society for American Archaeology 
Reichel-Dolmatoff was born in Salzburg on March 6, 1912, in what was then the Austro-Hungarian Empire. His secondary education was oriented to the classics (Latin and Greek) at the Benedictine school of Kremsmünster in Austria (1923-1931). He graduated in fine arts from the Akademie der Bildenden Künste (1934-1936) in Munich, Germany. He then moved to Paris where he attended both the Falculté des Lettres of the Sorbonne and the Université de Paris, Ecole du Louvre (1937-1939). During his years in Paris, he attended lectures by Marcel Mauss and the sociologist George Gurvitch. In 1939 , on the eve of Second World War, he emigrated to Colombia under the advice of the French political scientist André Siegfried.

During the war years, he worked in paleontology for petroleum companies in Bogotá (1941-1946). He also was involved in conducting ethnological and archaeological research at the Instituto Etnológico Nacional (1941-1946), founded by his friend, the French ethnologist Paul Rivet, in exile in Colombia. His strong interest in conducting fieldwork made Gerardo travel all over the country from the jungles of the Amazon to the desert of Guajira, from the humid tropical forest of the Chocó to the savannas of the Llanos Orientales. This constant travel and intensive research without doubt led him to become the pioneer of most of the basic archaeological and ethnographic knowledge that we have of Colombia.

Reichel-Dolmatoff's research was the first to create the basic chronological framework for most of the country, and, as a consequence, it put Colombian archaeology in the international arena. His longlasting research program began in 1940 with a trip to the upper Meta River in the Orinoco plains, which generated one of the earliest published studies on the material culture of the Guahibo Indians. In 1941 he and Alicia Dussan Maldonado, an ethnologist, began archaeological research projects in the highlands at the Sabana de Bogotá. They conducted excavations in Sopó, Soacha, and in the lowlands near the Magdalena River close to the city of Girardot.

Gerardo became a Colombian citizen in 1942 and the following year he married Alicia Dussan, who was one of the first graduate students of the Instituto Etnológico Nacional directed by Paul Rivet. The two became a research team for the rest of Gerardo's life. From this union, four children were born. All have become prominent in their chosen fields; Helena pursued a research career in biology, while Ines and Elizabeth have followed their parents' interest in anthropology and archaeology. René became a painter, choosing to develop artistic skills that were also found in his father.

The diversity of research programs that Gerardo Reichel-Dolmatoff and Alicia Dussan undertook is clear in the publications of the Instituto Etnológico Nacional. In 1943 Gerardo published his first archaeological study on the Muisca settlement of Soacha. Also in 1943 he and Alicia conducted a comparative study on the burial urns of the Magdalena River published in the former journal of the Instituto Etnológico Nacional. In the same year they published a pioneer work on the blood type variations between the indigenous groups of the Pijao in the Department of Tolima.

In 1944 Gerardo made a research trip to the Sierra de Perija and published one of the most complete ethnographies on the Motilones (Yuko). He then continued to the west of the Sierra Nevada de Santa Marta, collecting data on the last survivors of the Chimila Indians in the tropical forest of the Ariguaní River.

In 1946 Gerardo and Alicia moved their residence to the city of Santa Marta where they established the Instituto Etnológico del Magdalena, which he directed until 1950. The years at Santa Marta provided the opportunity to conduct archaeological research at the site of Pueblito in the Parque Tairona, where for the first time a cultural sequence of the area was established. The first systematic archaeological research at Rancheria and the Cesar River was conducted as well.

Between 1946 and 1948 Gerardo carried out ethnographic fieldwork in the Sierra Nevada de Santa Marta collecting the data for his landmark monograph on the Kogi. He continued to visit the Sierra Nevada, obtaining information that has clarified our view of the ancestral Tairona chiefdoms of the Kogi.

Alicia and Gerardo were unstoppable researchers. They spent time in 1947 with the Cuna Indians at the Caiman Nuevo River, west of the Gulf of Urabá. Gerardo returned to this area in 1958 and revisited Arquía near the Darien Straight. After his work in Santa Marta, in 1951 and 1952 he and Alicia moved 


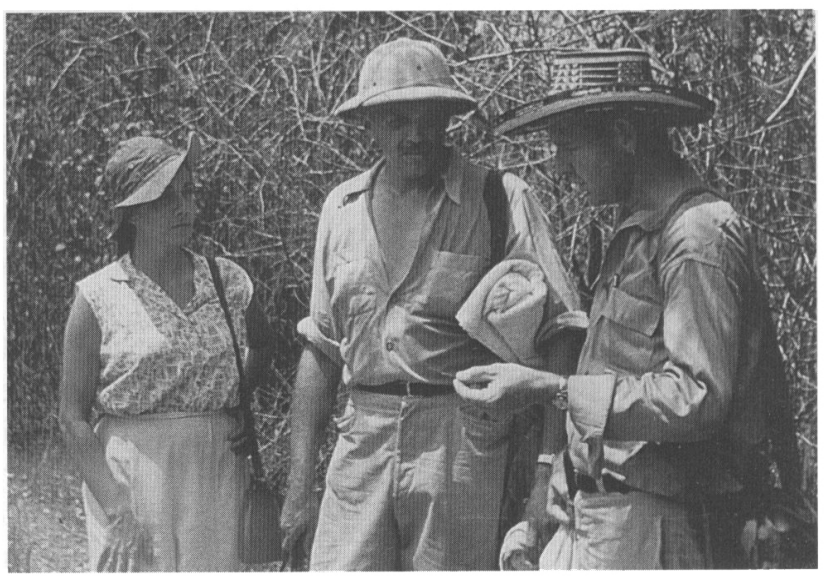

Alicia Dussan de Reichel, Reichel-Dolmatoff, and Clifford Evans on a trip to Barlovento in 1957. Photo courtesy Betty J. Meggers.

to the mestizo town of Aritama (Guajira). The results of their 14 months of fieldwork in this area became a classic anthropological study on a mestizo peasant society entitled The People of Aritama, published by the University of Chicago Press in 1961.

Gerardo Reichel-Dolmatoff's family moved again to Bogotá, where he became a research member of the new Instituto Colombiano de Antropología (1953-1960). From there he and Alicia continued their extensive research. In 1952 he made the first of numerous trips to the Vaupés territory. The work done in this area as well as that from the Sierra Nevada de Santa Marta would lead to many articles and books on indigenous cosmology (Amazonian Cosmos), including that of the Tukano (The Shaman and the Jaguar and Beyond the Milky Way). Some of these are fine examples of pioneer research in ethnoarchaeology. The same year he returned to the Sierra Nevada de Santa Marta, but this time he focused his ethnographic work on the Ika Indians of the southern drainage. After this trip, he published his classic ethnohistorical study on the cultural change of the Sierra Nevada de Santa Marta in which he demonstrated the relationship between the present-day Kogi and the ancient Tairona chiefdoms.

Between 1954 and 1960 Gerardo and Alicia made the Caribbean city of Cartagena a base for their research. Occasionally Gerardo taught classes in medical anthropology at the Faculty of Medicine at the Universidad de Cartagena. In 1954 he and Alicia located and excavated the site of Barlovento. This site was the first early Formative, shell-midden site found in Colombia. From Cartagena they launched the first archaeological survey of the lower Magdalena River and produced the first archaeological sequence of the areas of Plato, Zambrano, and Tenerife. Furthermore, in 1955 they began survey and excavations in the Gulf of Morrosquillo and a survey in the Sinú River drainage, creating the first archaeological sequence for the region ranging from the Preceramic site of San Nicolas up to the conquest. Of special significance was the excavation work at Momil, where for the first time in Colombian archaeology a study of subsistence change was undertaken. In 1957 they explored the headwaters of the Sinú River and undertook a pioneer study of the Engevara Indians, an Envera group. In 1958 they did the first archaeological study of the Gulf of Urabá and lower Atrato River in the Darien strait. In 1959 they continued archaeological research in the lower Magdalena River.

Returning to Bogotá in 1960 they began a three-year archaeological survey of the Pacific coast of Colombia between the Panamanian frontier and the Ecuadorian border. This research was supported by the Institute of Andean Research in New York. The survey was interrupted in 1961 by the first season of fieldwork at the site of Puerto Hormiga on the Caribbean coast, where Gerardo discovered what at the time was the earliest dated pottery in the New World. The same year he published the first explanation of the rise of chiefdom societies in Colombia in his now classic article "The Agricultural Basis of the 
Sub-Andean Chiefdoms of Colombia," published in the Venezuelan journal Antropologica. In 1963 he and Alicia moved again to Bogotá to create the first Department of Anthropology in Colombia at the Universidad de Los Andes. From there they finished the excavations at Puerto Hormiga during that same year. His time as chairman of the Department of Anthropology (1963-1969) was expended in teaching and preparing numerous papers and books such as the first synthesis of Colombian archaeology in English (Colombia: Ancient Peoples and Places). Even with the demands of publishing and administrative work at the department, Reichel-Dolmatoff never stopped his research. During 1966 he undertook a new archaeological research project in San Agustín that led to the publication of his book on this subject (San Agustin: A Culture of Colombia). He undertook trips to the Sierra Nevada de Santa Marta in 1966, and in 1968 to the Vaupés. In 1970 he received a visiting fellowship to Cambridge University. In 1974 he and Alicia recommenced a research project on the early Formative along the Caribbean coast. This time they excavated the important site of Monsu that allowed for the refinement of the chronology of the early Formative in the lowlands of northern Colombia. In the same year, Gerardo became adjunct professor in the Department of Anthropology at the University of California-Los Angeles, where occasionally he would give lectures and teach classes.

Reichel-Dolmatoff's achievements were well recognized. He was a Foreign Associate Member of the National Academy of Sciences in the United States (1976), Member of the Academia Real Española de Ciencias (1983), and Fellow of the Linnean Society (1989). The enormous contribution that Gerardo Reichel-Dolmatoff made to anthropology and archaeology was internationally recognized in 1975 when he was awarded the Thomas H. Huxley medal by the Royal Anthropological Institute of Great Britain and Ireland. In 1983 he become a founding member of the Third World Academy of Sciences. He was awarded numerous other distinctions and medals for his contribution to anthropology in Colombia and around the world.

Colombian and Latin American archaeology and anthropology have lost a brilliant scholar. Gerardo, however, leaves behind a rich legacy of academic achievement and a generation of young professional Colombian archaeologists and anthropologists who aspire to continue his high standards of research. The goals they pursue are the result of examples set by both Gerardo and Alicia, whose lives where filled with hard fieldwork, high-quality publications of research results, and constant intellectual challenges. Gerardo and Alicia will always be the jaguars and light of archaeology in the neotropics.

Augusto OYuELA-CAYCEDO

\section{Select Bibliography of Gerardo Reichel- Dolmatoff}

1943 Apuntes Arqueológicos de Soacha. Revista del Instituto Etnológico Nacional 1(1):15-26.

Las Urnas Funerarias en la Cuenca del Río Magdalena (with A. Dussan de Reichel). Revista del Instituto Etnólogico Nacional 1(2):209-281.

1945 Los Indios Motilones (Etnografia y Linguistica). Revista del Instituto Etnológico Nacional 2(1):15-115.

1947 La Cueva Funeraria de la Paz. Boletín de Arqueología 2(5-6):403-412.

1951 Investigaciones Arqueológicas en el Departamento del Magdalena, Colombia, 19461950. Parte I: Arqueología del Río Ranchería. Parte II: Arqueologia del Río Cesar, (with A. Dussan de Reichel). Boletín de Arqueología 3(1-6): 1-334.

Datos Histórico-Culturales sobre las Tribus de la
Antigua Gobernación de Santa Marta. Banco de la República, Bogotá.

1953 Contactos y Cambios Culturales en la Sierra Nevada de Santa Marta. Revista Colombiana de Antropologia 1(1):15-122.

Investigaciones Arqueológicas en el Departamento del Magdalena: 1946-1950; Parte III Arqueología del Bajo Magdalena, (with A. Dussan de Reichel). Divulgaciones Etnólogicas 3(4):1-96.

1954 A Preliminary Study of Space and Time Perspective in Northern Colombia. American Antiquity 19:352-365.

Investigaciones Arqueológicas en la Sierra Nevada de Santa Marta; Partes 1 y 2. Revista Colombiana de Antropología 2(2):145-206.

Investigaciones Arqueológicas en la Sierra Nevada de Santa Marta; Parte 3, Sitios de Contacto Español en Pueblito. Revista Colombiana de Antropología 3:139-170.

Contribuciones a la Arqueología del Bajo 
Magdalena (Plato, Zambrano, Tenerife), (with A. Dussan de Reichel). Divulagaciones Etnólogicas 3(5):145-163.

1955 Excavaciones en los Conchales de la Costa de Barlovento. Revista Colombiana de Antropología 4:247-272.

Investigaciones Arqueológicas en la Sierra Nevada de Santa Marta; Parte 4, Sitios de Habitación del Período Tairona II, en Pueblito, (with A. Dussan de Reichel). Revista Colombiana de Antropología 4:191-245.

1957 Momil: A Formative Sequence from the Sinu Valley. American Antiquity 22:226-234.

1961 Investigaciones Arqueológicas en la Costa Pacífica de Colombia. 1: El sitio Cupica. Revista Colombiana de Antropología 10:237-330.

The Agricultural Basis of the Sub-Andean Chiefdoms of Colombia. The Evolution of Horticultural Systems in Native South America: Causes and Consequences, edited by J. Wilbert. A special issue of Antropológica 2:83-100.

Anthropomorphic Figurines from Colombia: Their Magic and Art. In Essays in PreColumbian Art and Archaeology, edited by Samuel Lothrop et al., pp. 229-241. Harvard University Press, Cambridge.

The People of Aritama: The Cultural Personality of a Colombian Mestizo Village (with A. Dussan de Reichel). University of Chicago Press, Chicago.

1962 Investigaciones Arqueológicas en la Costa Pacífica de Colombia. II: Una Secuencia Cultural del Bajo Río San Juan (with A. Dussan de Reichel). Revista Colombiana de Antropología 11:169-188.

1965 Excavaciones Arqueológicas en Puerto Hormiga (Departamento de Bolivar). Ediciones de la Universidad de los Andes, Bogotá.

Colombia: Ancient Peoples and Places. Thames and Hudson, London.

1971 Amazonian Cosmos; The Sexual and Religious Symbolism of the Tukano Indians. University of Chicago Press, Chicago.

1972 San Agustin: A Culture of Colombia. Praeger, New York.

1975 Contribuciones al Conocimiento de la Estratigrafia Cerámica de San Agustín, Colombia. Biblioteca Banco Popular, Bogotá.

The Shaman and the Jaguar: A Study of Narcotic Drugs among the Indians of Colombia. Temple University Press, Philadelphia.

1976 Cosmology as Ecological Analysis: A View from the Rain Forest. Man 11(3):307-318.

1977 Estudios Antropológicos (with A. Dussan de Reichel). Instituto Colombiano de Cultura, Bogotá.

1978 Beyond the Milky Way: Hallucinatory Imagery of the Tukano Indians. Latin American Center Publications, Latin American Studies, vol. 42. University of California, Los Angeles.

El Chaman y el Jaguar: Estudio de las Drogas Narcoticas entre los Indios de Colombia. Siglo Veintiuno Editores, Mexico.

1979 Desana Shaman's Rock Crystals and the Hexagonal Universe. Journal of Latin American Lore 5(1)117-128.

1982 Astronomical Models of Social Behavior among Some Indians of Colombia. In Ethnoastronomy and Archaeastronomy in the American Tropics, edited by A. F. Aveni and G. Urton, pp. 165-181. Annals of the New York Academy of Science Vol. 385. New York Academy of Science, New York.

1985 Los Kogi: Una Tribu de la Sierra Nevada de Santa Marta, Colombia. Procultura, 2a ed. Bogotá.

Monsú: Un Sitio Arqueológico., Biblioteca Banco Popular, Bogotá.

Basketry as Metaphor: Arts and Crafts of the Desana Indians of the Northwest Amazon. Occasional papers of the Museum of Cultural History, University of California, Los Angeles.

1986 Arqueologia de Colombia: Un Texto Introductorio. Fundación Segunda Expedición Botanica, Bogotá.

1987 Shamanism and Art of the Eastern Tukanoan Indians: Colombian Northwest Amazon. E. J. Brill, New York.

1988 Goldwork and Shamanism: An Iconographic Study of the Gold Museum. Compañia Litografica Nacional S.A., Medellín.

1989 Desana Text and Context. Acta Ethnologica et Lingüística, No. 62, Series Americana 12, Vienna-Foehrenau.

1990 The Sacred Mountain of Colombia's Kogi Indians. Iconography of Religions. Section IX, South America,; fasc. 2, E. J. Brill, New York.

1991 Arqueología del Bajo Magdalena: Estudio de la Cerámica de Zambrano (with A. Dussan de Reichel). Banco Popular-Colcultura, Bogotá.

Los Ika: Sierra Nevada de Santa Marta, Colombia: Notas Etnograficas, 1946-1966. Centro Editorial, Universidad Nacional de Colombia, Bogotá.

\section{Notes}

The photograph of Reichel-Dolmatoff in Venice in 1993 has been generously supplied by Alicia and Helena Reichel. A complete bibliography of Gerardo and Alicia's works that includes more than 200 titles updated to 1990 was published in Colombia on the occasion of Reichel-Dolmatoff's award of the Premio Nacional Merito Cientifico by the Asociación Colombiana para el Avance de la Ciencia y Granahorrar (1992) and of the Doctorado Honoris Causa (1992) by the Universidad de los Andes. 